\title{
Phenoxazinone Biosynthesis: Accumulation of a Precursor, 4-Methyl-3-hydroxyanthranilic Acid, by Mutants of Streptomyces parvulus
}

\author{
By THOMAS TROOST AND EDWARD KATZ \\ Department of Microbiology, \\ Georgetown University, Schools of Medicine and Dentistry, \\ Washington, D.C. 20007, U.S.A.
}

(Received 27 June 1978; revised 6 September 1978)

\begin{abstract}
Mutants of Streptomyces parvulus that are blocked in the synthesis of the phenoxazinonecontaining antibiotic, actinomycin, were isolated by the 'agar piece' method (after ultraviolet irradiation or treatment with 8-methoxypsoralen plus near-ultraviolet light). Radiolabelling experiments in conjunction with paper, thin-layer and column chromatography revealed that 4-methyl-3-hydroxyanthranilic acid (MHA) is a major metabolite accumulated by these mutants. Studies in vitro and in vivo provided evidence that MHA is a precursor of the phenoxazinone chromophore, actinocin. Normally MHA does not accumulate during growth or antibiotic synthesis by the parental strains. Protoplasts derived from the mutant strain AM5 synthesized MHA in significant amounts. A scheme is proposed for the biosynthesis of actinomycin $D$ that accounts for the accumulation of MHA by the mutants.
\end{abstract}

\section{INTRODUCTION}

The actinomycins constitute a family of chromopeptide antibiotics which differ only in the amino acids present in the pentapeptide chains (Meienhofer \& Atherton, 1973). The actinomycin chromophore (actinocin) is 2-amino-4,6-dimethylphenoxazin-3-one-1,9-dicarboxylic acid (Meienhofer \& Atherton, 1973). Phenoxazinone structures are also present in the ommochromes produced by arthropods and molluscs (Butenandt, 1957; Linzen, 1974) and in pigments elaborated by certain fungi (e.g. Polystictus cinnabarinus) and by streptomycetes (Gerber, 1973; Achenbach \& Worth, 1977). Phenoxazinones have also been found in other microbial metabolites such as the antibiotics questiomycin $\mathrm{A}$ and acetylquestiomycin A (Gerber, 1973).

Genetic, biochemical and chemical investigations have revealed that tryptophan and certain of its metabolites are precursors for phenoxazinone biosynthesis. The classic investigations of Tatum (1939) and Tatum \& Haagen-Smit (1941) and those of Butenandt and co-workers (Butenandt et al., 1940, 1949; Butenandt \& Beckmann, 1955; Butenandt \& Neubert, 1955) established that there is a relationship between tryptophan metabolism and eye pigment formation in Drosophila and other insects. Several lines of evidence have also demonstrated that the catabolism of tryptophan is necessary for the synthesis of the actinomycin chromophore in Streptomyces antibioticus (Katz \& Weissbach, 1967).

As a precursor-product relationship between tryptophan and nicotinic acid and the nicotinyl coenzymes has been demonstrated in higher animals (Chaykin, 1967), fungi (Beadle et al., 1947; Ahmad \& Moat, 1966) and certain bacteria (Wilson \& Henderson, 1963; Lingens \& Vollprecht, 1964; Lingens et al., 1966), it is evident that a common path- 


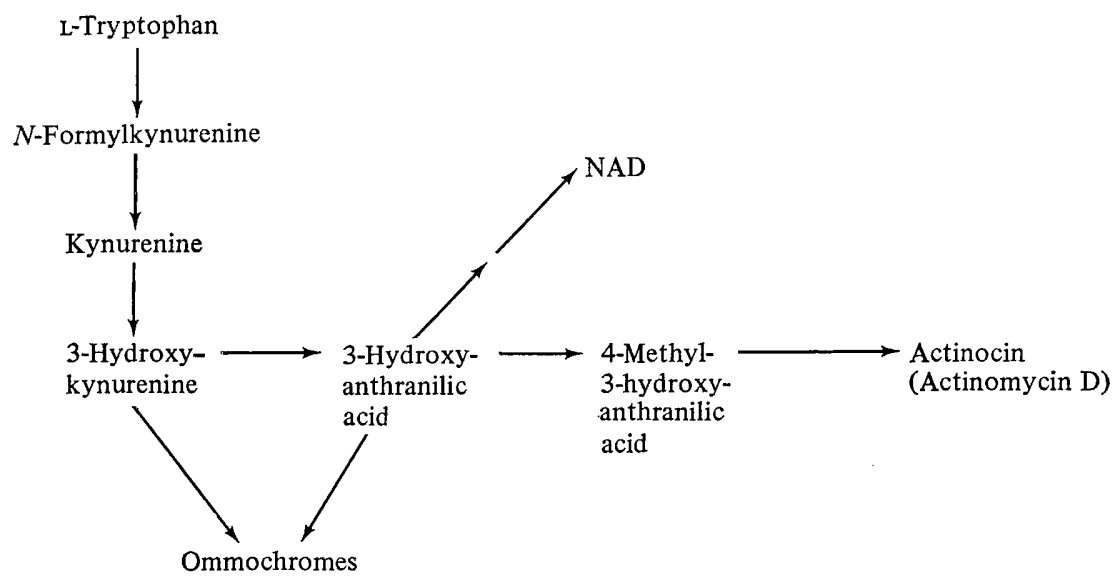

Fig. 1. Relationship of tryptophan to NAD, actinomycin and ommochrome biosynthesis.

way provides the precursor(s) needed for the biosynthesis of these diverse metabolic products (Fig. 1).

The present paper describes experiments aimed at elucidating further the biosynthetic steps whereby tryptophan is converted to actinocin. Mutants of Streptomyces parvulus blocked in the synthesis of actinomycin D were examined, and non-producing (Act ${ }^{-}$) and low-producing (Act*) strains were isolated that were found to accumulate 4-methyl-3hydroxyanthranilic acid.

\section{METHODS}

Abbreviations. MHA, 4-Methyl-3-hydroxyanthranilic acid; GYM, glucose/yeast extract/malt extract medium; GHF, glutamic acid/histidine/fructose medium; MOP, 8-methoxypsoralen; NTG, $N$-methyl$N^{\prime}$-nitro- $N$-nitrosoguanidine; Act ${ }^{-}$, actinomycin negative; Act*, low actinomycin producer.

Chemicals. MHA was kindly supplied by Dr A. B. Mauger, Washington Hospital Center, Washington, D.C., U.S.A. Anthranilic acid was from S. B. Penick \& Co., New York, N.Y., U.S.A.; 3-hydroxyanthranilic acid was from Mann Research Laboratories, Orangeburg, N.Y., U.S.A.; L-3-hydroxykynurenine (free base) and L-tryptophan were from Calbiochem. Dowex-1 chloride (1-X8, 400 mesh) was obtained from Sigma, and silicic acid (100 mesh, no. 2847) from Mallinkrodt Chemical Works, St Louis, Mo., U.S.A.

L-[U-14C]Tryptophan (specific activity, $\left.566 \mathrm{mCi} \mathrm{mmol}^{-1}\right), \mathrm{L}-\left[\right.$ methyl $\left.-{ }^{14} \mathrm{C}\right]$ methionine $\left(57.5 \mathrm{mCi} \mathrm{mmol}^{-1}\right)$, $\left[1-^{14} \mathrm{C}\right]$ glycine $\left(46 \cdot 9 \mathrm{mCi} \mathrm{mmol}^{-1}\right)$, L-[U-14 $\left.\mathrm{C}\right]$ threonine $\left(158 \cdot 7 \mathrm{mCi} \mathrm{mmol}^{-1}\right), \mathrm{L}-\left[\mathrm{U}_{-}^{-14} \mathrm{C}\right]$ valine $\left(232 \cdot 6 \mathrm{mCi} \mathrm{mmol}^{-1}\right)$ and L-[side chain-3-14 C]tryptophan $\left(56.8 \mathrm{mCi} \mathrm{mmol}^{-1}\right)$ were obtained from New England Nuclear Corp. DL-[benzene ring-U- $\left.{ }^{14} \mathrm{C}\right]$ Tryptophan $\left(60 \mathrm{mCi} \mathrm{mmol}^{-1}\right)$ and $\mathrm{L}-\left[\mathrm{U}-{ }^{14} \mathrm{C}\right]$ proline $\left(238.1 \mathrm{mCi} \mathrm{mmol}^{-1}\right)$ were purchased from Amersham/Searle Corp., Arlington Heights, Ill., U.S.A. $\left[{ }^{14} \mathrm{C}\right]$ MHA was prepared as described under 'Large-scale radioisotope experiments' and 'Chromatographic procedures'.

Organisms and conditions of cultivation. Streptomyces parvulus (ATCC 12434) synthesizes actinomycin D; two higher-yielding strains (C and $\mathrm{C}$ ) were obtained by cloning the organism using the 'agar piece' method of Ichikawa et al. (1971) and were then employed for the isolation of the mutants used in the present investigation. Streptomyces antibioticus (Rutgers Institute of Microbiology, strain 3720) was the source of phenoxazinone synthase. Bacillus subtilis (ATCC 6633) was the test organism for microbiological assays.

Streptomyces parvulus and S. antibioticus were maintained on slants of GYM agar medium (Hook \& Vining, 1973). They were grown in appropriate liquid media as previously described (Gallo \& Katz, 1972; Hook \& Vining, 1973; Williams \& Katz, 1977).

Bacillus subtilis was grown overnight on slants of nutrient agar at $37^{\circ} \mathrm{C}$. A spore suspension was prepared as described by Grove \& Randall (1955) except that the organism was grown in $250 \mathrm{ml}$ Erlenmeyer flasks containing $75 \mathrm{ml}$ sporulation medium no. 32 (Kramer et al., 1968) at $37^{\circ} \mathrm{C}$ on a gyratory shaking incubator for 3 to $5 \mathrm{~d}$.

The resulting spore suspension and all slants were stored at $4{ }^{\circ} \mathrm{C}$.

Single spore preparations for cloning and mutagenesis. Spores of $S$. parvulus were gently scraped from the surface of a GYM agar slant into $10 \mathrm{ml} 0 \cdot 1 \%(\mathrm{v} / \mathrm{v})$ Triton X-100 in 0.1 M-sodium phosphate buffer, $\mathrm{pH} 7 \cdot 0$. The spore suspension was vortexed vigorously, filtered by gentle suction filtration (Whatman GF/C 
filter) and the filtrate was collected in a sterile tube placed inside the filter flask (Parada, 1975). By phase contrast microscopy, it was established that this procedure yielded essentially a monoconidial preparation.

Cloning of $S$. parvulus cultures for higher-yielding strains. A suitable dilution of the monoconidial preparation $(0.1 \mathrm{ml})$ was spread over the surface of GYM agar plates and incubated at $30^{\circ} \mathrm{C}$ for $48 \mathrm{~h}$; at this time colonies were discernible, but no significant amount of antibiotic was made. The 'agar piece' method (Ichikawa et al., 1971) was used to isolate higher-yielding strains. Colonies with the largest zones of inhibition were isolated by streaking on GYM agar plates. After incubation, the $S$. parvulus strains selected were maintained on GYM agar slants. Production of actinomycin was tested in GHF and GYM liquid media over $8 \mathrm{~d}$ at $30^{\circ} \mathrm{C}$. The strain of $S$. parvulus yielding the highest actinomycin titre was recloned by the same procedures.

Preparation of protoplasts of $S$. parvulus. Protoplasts of $S$. parvulus were prepared by a modification (Hitchcock \& Katz, 1978) of the method described by Keller \& Kleinkauf (1977). Mycelium was harvested after $48 \mathrm{~h}$ growth in GHF liquid medium.

Mutagenic treatment of S. parvulus. Spores of S. parvulus were treated for 30 min with MOP at $10 \mu \mathrm{g} \mathrm{ml}^{-1}$ and then exposed to near-ultraviolet light ( $15 \mathrm{~W}$ lamp) for $7.5 \mathrm{~min}$ at a distance of $7.0 \mathrm{~cm}$, according to the method of Townsend et al. (1971).

Ultraviolet light was employed as a mutagenic agent as described by Kelner (1948). A spore suspension $(10 \mathrm{ml}$ in a $10 \mathrm{~cm}$ diam. Petri dish) was irradiated with a $15 \mathrm{~W}$ germicidal lamp (General Electric Co.) while being stirred. The ultraviolet light intensity was $4 \mathrm{~J} \mathrm{~m}^{-2}$, resulting in a $99 \%$ killing with a dose of $200 \mathrm{~J} \mathrm{~m}^{-2}$.

The method of Delić et al. (1970) was used with NTG. The monoconidial preparation was treated with NTG at $2.0 \mathrm{mg} \mathrm{ml}^{-1}$ in $0.05 \mathrm{M}$-Tris/maleic acid buffer, $\mathrm{pH} 9.0$, for 15 or $30 \mathrm{~min}$ (giving approximately a $1 \%$ survival) at $30^{\circ} \mathrm{C}$; the spores were washed free of the mutagen by suction filtration with $0.1 \mathrm{M}$-sodium phosphate buffer, $\mathrm{pH} 7 \cdot 0$.

After mutagenic treatment, the 'agar piece' method was used to screen for mutants of $S$. parvulus that failed to synthesize (Act-) or were low antibiotic producers (Act*).

Short-term radiolabelling experiments. These were based on the procedure of Katz \& Weissbach (1963) except that $5 \mathrm{ml}$ portions of a $72 \mathrm{~h}$ culture previously grown in GHF medium were incubated for 10 or $60 \mathrm{~min}$ (unless stated otherwise). The culture filtrate and mycelium were extracted as follows. (i) Butanol extract: the mycelium trapped on the glass wool was washed with cold deionized water $(3 \times 5 \mathrm{ml})$ and then extracted for $1 \mathrm{~h}$ in $4 \mathrm{ml}$ 1-butanol; the supernatant was collected after low speed centrifugation. (ii) 'Neutral' and (iii) 'acidic' ethyl acetate extracts: these were prepared as described by Katz \& Weissbach (1963) and Beaven et al. (1967), respectively; after shaking and centrifugation, the organic layer was recovered. All three extracts were examined by chromatography and measurements of radioactivity.

Large-scale radioisotope experiments. Cultures of $S$. parvulus were grown for $72 \mathrm{~h}$ in GHF medium. Chloramphenicol $\left(30 \mu \mathrm{g} \mathrm{ml}^{-1}\right.$, final concentration) and the radiolabelled precursor, L-[U-14 $\left.{ }^{14}\right]$ tryptophan ( $7 \mu \mathrm{Ci}, 0 \cdot 012 \mu \mathrm{mol}$ for one flask) or L-[methyl $\left.{ }^{14} \mathrm{C}\right]$ methionine $(16 \cdot 3 \mu \mathrm{Ci}, 0.32 \mu \mathrm{mol}$ for three flasks), were then added and incubation was continued for $120 \mathrm{~min}$ at $30^{\circ} \mathrm{C}$. The mycelium was collected by suction filtration through Whatman no. 42 filter paper in a Buchner funnel and washed with 0.5 vol. deionized water. The filtrate and the water wash were combined and extracted twice with 2 vol. ethyl acetate. After acidification to $\mathrm{pH} 2.5$ with $1 \mathrm{M}-\mathrm{HCl}$, the solution was re-extracted twice with 2 vol. ethyl acetate. The 'neutral' and 'acidic' ethyl acetate fractions were washed with 0.5 vol. deionized water and evaporated to dryness under vacuum.

Synthesis of 4-MHA by protoplast suspensions. Incubation mixtures contained $0.1 \mathrm{ml}$ of protoplasts, $0.05 \mathrm{ml}$ of ${ }^{14} \mathrm{C}$-labelled amino acid [DL-tryptophan $(0.38 \mu \mathrm{Ci}, 6.33 \mathrm{nmol})$ or L-methionine $(0.39 \mu \mathrm{Ci}$, $7.97 \mathrm{nmol}$ )] and $0.05 \mathrm{ml}$ of double-strength protoplast buffer in $18 \times 150 \mathrm{~mm}$ test tubes (Hitchcock \& Katz, 1978). The tubes were shaken at $30^{\circ} \mathrm{C}$ and $120 \mathrm{rev} \cdot \mathrm{min}^{-1}$ on a Dubnoff metabolic shaker for various periods and assayed as described by Hitchcock \& Katz (1978). Also, the 'neutral' and 'acidic' ethyl acetate fractions were analysed by thin-layer chromatography and measurements of radioactivity.

Incubation of washed mycelium with $\left[{ }^{14} \mathrm{C}\right] \mathrm{MHA}$. Streptomyces parvulus (C1) was harvested from GHF medium after $72 \mathrm{~h}$ growth by suction filtration through Whatman no. 2 filter paper in a Buchner funnel. The mycelium was washed with 0.5 (original) vol. physiological saline and immediately incubated with $\left[{ }^{14} \mathrm{C}\right]$ MHA (10 $10^{5}$ c.p.m.) for $90 \mathrm{~min}$ as described by Golub et al. (1969). The reaction was stopped by filtration through glass wool; the filtrate was then extracted under 'neutral' $(\mathrm{pH} 8.0)$ and 'acidic' ( $\mathrm{pH} 2.5)$ conditions, and the mycelium was extracted with 1-butanol as noted above.

Incubation of $\left.{ }^{[14} \mathrm{C}\right] M H A$ with phenoxazinone synthase. Extracts were prepared from $S$. antibioticus according to the method of Katz \& Weissbach (1962). For the enzymic incubation, $\left[{ }^{14} \mathrm{C}\right] M H A\left(10^{5}\right.$ c.p.m.) obtained from the Dowex-1 chloride column was mixed with $750 \mu$ mol sodium acetate buffer, pH 5.3, deionized water and $40 \mu \mathrm{l}$ of the 20 to $60 \%\left(\mathrm{NH}_{4}\right)_{2} \mathrm{SO}_{4}$ fraction in a final volume of $3 \mathrm{ml}$. After incubation for $20 \mathrm{~min}$ at $37^{\circ} \mathrm{C}$, the reaction mixture was adjusted with $1 \mathrm{M}-\mathrm{HCl}$ to $\mathrm{pH} 2 \cdot 5$, and the acidified solution 
was extracted with $6 \mathrm{ml}$ ethyl acetate ('Short-term radiolabelling experiments') and analysed. A control incubation with boiled enzyme was included.

Analytical methods. Actinomycin formation by $S$. parvulus was measured by a spectrophotometric procedure in a Zeiss PMQ II spectrophotometer at $443 \mathrm{~nm}$ (Katz \& Weissbach, 1963) and by a disk diffusion method with $B$. subtilis (Kramer et al., 1968).

Chromatographic procedures. The 'neutral' and 'acidic' ethyl acetate extracts were evaporated to dryness at $30^{\circ} \mathrm{C}$; 1-butanol extracts were evaporated at 55 to $60^{\circ} \mathrm{C}$ under reduced pressure on a Buchi rotavapor and/or Evapo-Mix (Buchler Instruments, Fort Lee, N.J., U.S.A.). Samples were then dissolved in $50 \mu 1$ methanol and applied to the chromatographic paper or thin-layer plates.

Ascending paper chromatography on Whatman no. 1 filter paper $(46 \times 40 \mathrm{~cm})$ was carried out using the solvents: 1 , methanol/water/pyridine $\left(4: 1: 2\right.$, by vol.) $\left(R_{F}\right.$ for $\left.\mathrm{MHA}=0 \cdot 7\right) ; 2,1$-butanol/acetic acid/ water ( $4: 1: 5$, by vol., upper phase) $\left(R_{F}\right.$ for MHA $\left.=0 \cdot 85\right)$.

Thin-layer chromatography (t.l.c.) was done on $20 \times 20 \mathrm{~cm}$ silica gel $60 \mathrm{~F}_{254}$ plates $(0.25 \mathrm{~mm}$ thickness; Merck) with solvents: 1 , chloroform/glacial acetic acid $\left(90: 10\right.$, by vol.) $\left(R_{F}\right.$ for $\left.\mathrm{MHA}=0 \cdot 34\right) ; 2$, ethyl acetate/methanol/water (100:5:5, by vol.) $\left(R_{F}\right.$ for MHA $\left.=0 \cdot 84\right)$.

The position and identity of the metabolites on chromatograms were determined by visualization with an ultraviolet lamp (Mineralite UVS-11, Ultraviolet Products, San Gabriel, Calif., U.S.A.) and by staining with ninhydrin, Ehrlich's, alkaline silver nitrate and Ekman's reagents (Krebs et al., 1969).

The 'acidic' ethyl acetate-extractable metabolites isolated from the $S$. parvulus mutant AM5 ('Large-scale radioisotope experiments') were also analysed by silicic acid and Dowex-1 chloride column chromatography (Weissbach et al., 1965a, b). For each column, radioactive metabolites plus carrier MHA were dissolved in a small amount of the appropriate solution, applied to the column (each $11 \mathrm{~cm} \times 1 \mathrm{~cm} \mathrm{diam}$.) and eluted as described by Weissbach et al. $(1965 a, b)$. Fractions were monitored spectrophotometrically for MHA and by measurements of radioactivity.

Radioactivity measurements. Radioactive metabolites on chromatograms were detected by autoradiography using Dupont Cronex 4 daylight pack or Kodak SB-5 X-ray film. Paper chromatograms were also examined with a Packard Autoradiochromatogram Scanner (Packard Instruments Co., Downers Grove, Ill., U.S.A.). Liquid samples were counted in a refrigerated Mark I Nuclear Chicago liquid scintillation spectrometer with $10 \mathrm{ml}$ scintillation fluid (Bray, 1960).

\section{RESULTS}

\section{Cloning of $S$. parvulus and mutant isolation}

The uncloned, parent strain of $S$. parvulus synthesized 490 to $505 \mu \mathrm{g}$ actinomycin D $\mathrm{ml}^{-1}$ during $144 \mathrm{~h}$ incubation in GHF medium. After cloning twice by the 'agar piece' method, a higher-yielding strain, $S$. parvulus (C), was obtained; this synthesized $575 \mu \mathrm{g} \mathrm{ml}^{-1}$ during $144 \mathrm{~h}$ incubation. The (C) strain was similarly cloned twice, resulting in the isolation of an even higher-yielding organism, $S$. parvulus $(\mathrm{C} 1)$, that synthesized actinomycin D for an additional $48 \mathrm{~h}$ giving a final titre of $675 \mu \mathrm{g} \mathrm{ml}^{-1}$ after $192 \mathrm{~h}$.

Spores of $S$. parvulus (C) were treated with MOP in the presence of near-ultraviolet light to give 1 to $5 \%$ survival. Some 5900 colonies were examined by the 'agar piece' method and 26 were found to be Act ${ }^{-}$or Act*. Sixteen of the 26 mutants proved to be Act ${ }^{-}$or Act* following cultivation under shaken conditions in GHF and GYM media. These cultures were analysed in short-term radiolabelling experiments with $\mathrm{L}-\left[\right.$ methyl $\left.-{ }^{14} \mathrm{C}\right]-$ methionine and DL-[benzene ring-U- $\left.{ }^{14} \mathrm{C}\right]$ tryptophan. Examination of paper chromatograms (solvents 1 and 2) with ultraviolet light, as well as by radiochromatogram scanning procedures, demonstrated that only one strain, AM5, appeared to synthesize MHA concomitantly with the formation of reduced levels of actinomycin D (40 to $200 \mu \mathrm{g} \mathrm{ml}^{-1}$ after $144 \mathrm{~h}$ ).

Additional mutants that accumulated MHA were isolated following irradiation of S. parvulus (C1) with ultraviolet light. From 900 colonies examined by the 'agar piece' method, four of the five Act ${ }^{-}$or Act* mutants detected were found to produce MHA, as determined by short-term radiolabelling experiments and the presence of a blue fluorescent compound with the same $R_{F}$ value as MHA on t.l.c. plates. The actinomycin D titres of the MHA-accumulating mutants obtained by ultraviolet irradiation ranged from 0 to $180 \mu \mathrm{g} \mathrm{ml}^{-1}$ after $168 \mathrm{~h}$. 


\section{Table 1. Incorporation of ${ }^{14} \mathrm{C}$-labelled amino acids into ethyl acetate-extractable metabolites}

Five $\mathrm{ml}$ of a $72 \mathrm{~h}$ culture of $S$. parvulus (C or AM5) were added to $0.05 \mathrm{ml}$ of the ${ }^{14} \mathrm{C}$-labelled amino acid in a $50 \mathrm{ml}$ Erlenmeyer flask and incubated with shaking for $1 \mathrm{~h}$ at $30^{\circ} \mathrm{C}$. The amino acids were: DL-[benzene ring-U- $\left.{ }^{14} \mathrm{C}\right]$ tryptophan $\left(5.72 \times 10^{5}\right.$ c.p.m., $\left.8 \mathrm{nmol}\right)$, L- $[$ methyl-14 $\mathrm{C}]$ methionine $\left(4.29 \times 10^{5}\right.$ c.p.m., $\left.4.8 \mathrm{nmol}\right)$, L-[U- ${ }^{14}$ C]threonine $\left(4.44 \times 10^{5}\right.$ c.p.m., $\left.1.8 \mathrm{nmol}\right), \quad$ L-[U-14C]valine $\left(4 \cdot 17 \times 10^{5}\right.$ c.p.m., $\left.1.2 \mathrm{nmol}\right), \quad$ L-[U-14 C]proline $\left(4.99 \times 10^{5}\right.$ c.p.m., $\left.1.4 \mathrm{nmol}\right)$ and $\left[1-{ }^{14} \mathrm{C}\right]$ glycine (3.48 $\times 10^{5}$ c.p.m., $\left.4 \cdot 8 \mathrm{nmol}\right)$, Assays were carried out as described in Methods.

$\begin{array}{lcccc}\text { 14 C-labelled } & \overbrace{\begin{array}{l}\text { Neutral } \\ \text { extract }\end{array}}^{\text {S. parvulus (C) }} & \begin{array}{c}\text { Acidic } \\ \text { extract }\end{array} & \overbrace{\begin{array}{c}\text { Neutral } \\ \text { extract }\end{array}}^{\text {R. parvulus AM5 }} & \begin{array}{c}\text { Acidic } \\ \text { extract }\end{array} \\ \quad \begin{array}{l}\text { amino acid } \\ \text { DL-Tryptophan }\end{array} & 56240 & 3640 & 13440 & 6580 \\ \text { L-Methionine } & 55540 & 1240 & 14680 & 4500 \\ \text { L-Threonine } & 30100 & 660 & 7020 & 160 \\ \text { L-Valine } & 35800 & 400 & 7960 & 2500 \\ \text { L-Proline } & 40860 & 860 & 10800 & 260 \\ \text { Glycine } & 10080 & 180 & 1760 & 100\end{array}$

Eleven Act- ${ }^{-}$or Act* mutants were isolated from 2200 colonies examined after treatment of the (C1) parent with NTG. However, no strains were observed to accumulate the tryptophan metabolite.

\section{Incorporation of labelled precursors into metabolites produced by $S$. parvulus}

Since the preliminary results indicated that a number of the Act ${ }^{-}$and Act* mutants synthesized MHA, the formation of this metabolite was investigated more extensively using the $S$. parvulus AM5 strain. Comparison of the incorporation of radioisotopes (DL- $\left[\right.$ benzene ring-U- $\left.{ }^{14} \mathrm{C}\right]$ tryptophan and $\mathrm{L}-\left[\right.$ methyl $\left.-{ }^{14} \mathrm{C}\right]$ methionine) into ethyl acetateextractable metabolites by $S$. parvulus (C) and AM5 indicated that the mutant exhibited a diminished ability to form 'neutral' metabolites (Table 1). A similar response was noted with other antibiotic precursors (valine, glycine, threonine and proline). Labelled tryptophan and methionine were also converted into radioactive 'acidic' metabolites by both the parent and mutant strains (Table 1); however, the incorporation with the AM5 mutant was significantly greater. By contrast, there was little conversion of ${ }^{14} \mathrm{C}$-labelled threonine, glycine and proline into 'acidic' metabolites by either strain. The AM5 mutant did in-

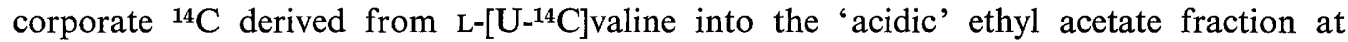
appreciable levels. However, during evaporation of the extract in preparation for chromatography, there was almost a complete loss of the radioactivity, suggesting that, during metabolism, valine was converted to its oxo acid derivative which is an unstable, volatile compound.

The incorporation of radioactivity from tryptophan and methionine into ethyl acetateextractable metabolites by the parent (C) and mutant (AM5) increased with time. Measurements of radioactivity on the t.l.c. plates (solvent 2) revealed that synthesis of the antibiotic by the mutant was only 5 to $10 \%$ (tryptophan) and $20 \%$ (methionine) of that by the $S$. parvulus (C) parent. Analysis of the 'acidic' ethyl acetate fraction by t.l.c. (solvent 1 ) indicated that ${ }^{14} \mathrm{C}$-labelled tryptophan and methionine were readily utilized for synthesis of MHA by the mutant; whereas the parent strain appeared to form only traces of the radioactive metabolite with $\left[{ }^{14} \mathrm{C}\right]$ tryptophan, and no MHA was ever detected using $\mathrm{L}-[$ methyl${ }^{14}$ C]methionine.

That the 'acidic' radioactive metabolites were derived from tryptophan and were 
Table 2. Effect of tryptophan metabolites on $\left[{ }^{14} \mathrm{C}\right]$ tryptophan incorporation into actinomycin ('neutral') and 'acidic' ethyl acetate-extractable material

Five $\mathrm{ml}$ of a $72 \mathrm{~h}$ culture of $S$. parvulus (C or AM5) were preincubated with tryptophan metabolites $\left(10^{-4} \mathrm{M}\right.$, final concentration) for $5 \mathrm{~min}$ prior to incubation with $\mathrm{DL}-\left[\right.$ benzene ring-U- $\left.{ }^{14} \mathrm{C}\right]-$ tryptophan $\left(6 \cdot 15 \times 10^{5}\right.$ c.p.m., $\left.8.6 \mathrm{nmol}\right)$ for $30 \mathrm{~min}$ at $30^{\circ} \mathrm{C}$. Assays were carried out as described in Methods.

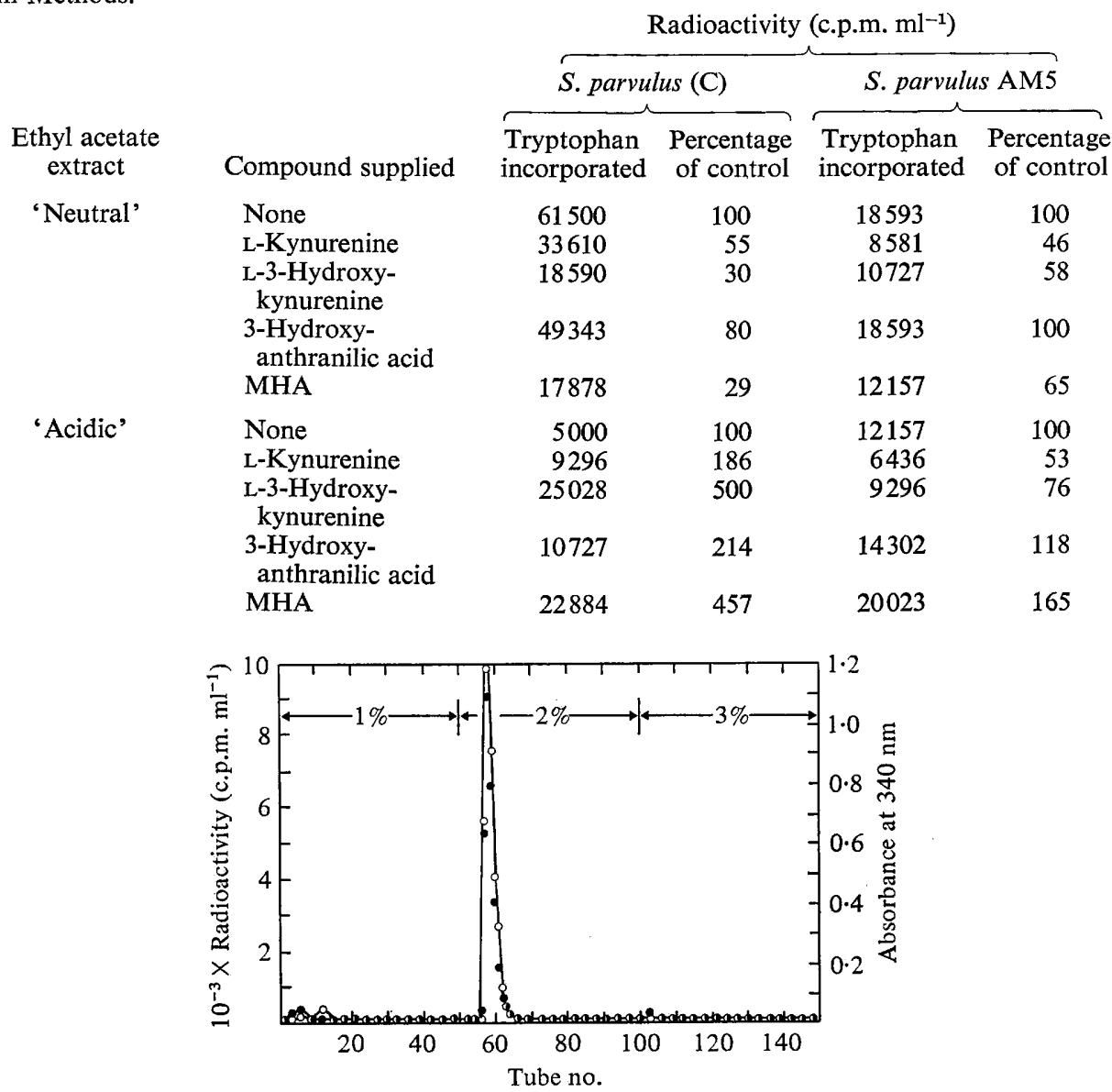

Fig. 2. Separation, on a silicic acid column, of radioactive metabolites from $S$. parvulus AM5 incubated with $\mathrm{L}-\left[\mathrm{U}-{ }^{14} \mathrm{C}\right]$ tryptophan as described in Methods. The metabolites $\left(10^{5}\right.$ c.p.m. plus $3 \mu \mathrm{mol}$ carrier MHA) in $1 \%$ methanol in benzene were applied to the column $(11 \mathrm{~cm} \times 1 \mathrm{~cm}$ diam. $)$, which was successively eluted with 1,2 and $3 \%$ methanol in benzene. Fractions of $2.5 \mathrm{ml}$ were collected and assayed for MHA by ultraviolet absorption at $340 \mathrm{~nm}(0)$ and for radioactivity (O) by scintillation counting. MHA was eluted with benzene containing $2 \%$ methanol. Approximately 80 to $85 \%$ of the total radioactivity applied was recovered in the peak region.

intermediates in actinomycin biosynthesis is further suggested by isotope dilution data (Table 2). Incorporation of $\left[{ }^{14} \mathrm{C}\right]$ tryptophan into the antibiotic by both the parent and mutant strains was markedly diminished in the presence of kynurenine, 3-hydroxykynurenine and MHA. With respect to the parent culture, there was a significant increase in ${ }^{14} \mathrm{C}$ in the acidic metabolites in the incubation mixtures to which the unlabelled compounds were added. The response of the mutant strain differed somewhat in that kynurenine and 3-hydroxykynurenine reduced the ${ }^{14} \mathrm{C}$ incorporated by 47 and $24 \%$, respectively, and the effect with 3-hydroxyanthranilic acid and MHA was less striking. Several additional experiments gave similar results. 


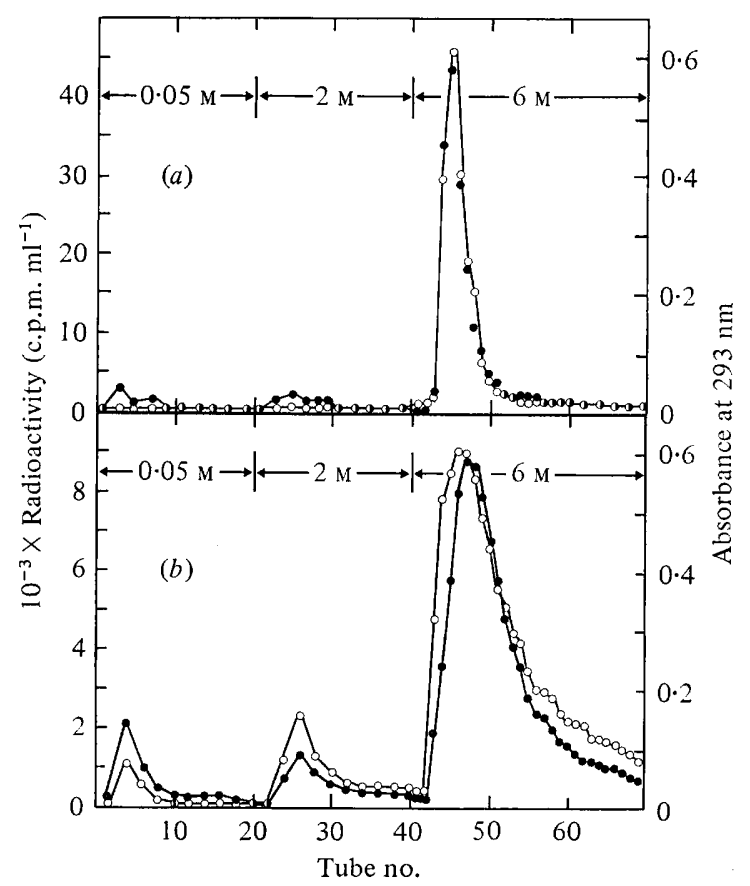

Fig. 3. Separation, on a Dowex-1 chloride column, of radioactive metabolites from $S$. parvulus AM5 $(a)$ and $S$. parvulus $(\mathrm{Cl})(b)$ incubated with $\mathrm{L}-\left[\mathrm{U}-{ }^{14} \mathrm{C}\right]$ tryptophan as described in Methods. The metabolites $\left(5 \times 10^{5}\right.$ c.p.m. plus $3 \mu \mathrm{mol}$ carrier MHA) were dissolved in the minimum amount of methanol; the solution was brought up to a total volume of $3 \mathrm{ml}$ with $0.05 \mathrm{M}$-sodium phosphate buffer, $\mathrm{pH} 7 \cdot 0$, and applied to the column $(11 \mathrm{~cm} \times 1 \mathrm{~cm}$ diam. $)$, which was successively eluted with $0.05,2.0$ and $6.0 \mathrm{M}$-acetic acid. Fractions of $2.0 \mathrm{ml}$ were collected, and $A_{293}(\odot)$ and radioactivity $(O)$ were measured. In $(a)$, about 80 to $90 \%$ of the radioactivity applied was recovered in the MHA region; in $(b)$, only $40 \%$ of the radioactivity applied was recovered in the major peak of radioactivity.

\section{MHA synthesis by $S$. parvulus AM5}

When AM 5 cultures were incubated with L-[methyl- $\left.{ }^{14} \mathrm{C}\right]$ methionine or L-[U_-14 $\left.\mathrm{C}\right]$ tryptophan and the 'acidic' ethyl acetate-extractable metabolites were subjected to silicic acid chromatography, a large peak of radioactivity was eluted with authentic MHA (Fig. 2). Similar results were obtained when the separation was carried out using Dowex-1 chloride column chromatography (Fig. $3 a$ ). The 'acidic' ethyl acetate-extractable, ${ }^{14} \mathrm{C}$-labelled metabolites synthesized by $S$. parvulus $(\mathrm{C})$ and $(\mathrm{C} 1)$ under similar incubation conditions were subjected to the same analyses. However, column chromatography failed to reveal that there was complete identity between the major ${ }^{14} \mathrm{C}$-labelled metabolite(s) synthesized and authentic MHA. For example, Dowex-1 chloride chromatography gave a broader elution profile (Fig. $3 b$ ) and the ${ }^{14} \mathrm{C}$-labelled material eluted somewhat earlier than the carrier MHA.

T.1.c. and autoradiography of the purified ${ }^{14} \mathrm{C}$-labelled material eluted from the peak region of the silicic acid or Dowex-1 chloride columns (AM5 studies) showed that the AM5 metabolite co-migrated with carrier MHA and comprised approximately 46 to $50 \%$ of the total radioactivity (Fig. 4). Examination of the peak eluate fractions of radioactive material derived from the parent strain revealed that only $6 \%$ of the radioactivity comigrated with MHA, while $61 \%$ remained at the origin (Fig. 4). This further confirmed that MHA was not a major metabolite accumulated by the parent during synthesis of actinomycin D.

When the AM5 metabolite, purified on the column, was incubated with phenoxazinone synthase, the product formed had similar chemical and spectral as well as chromatographic 


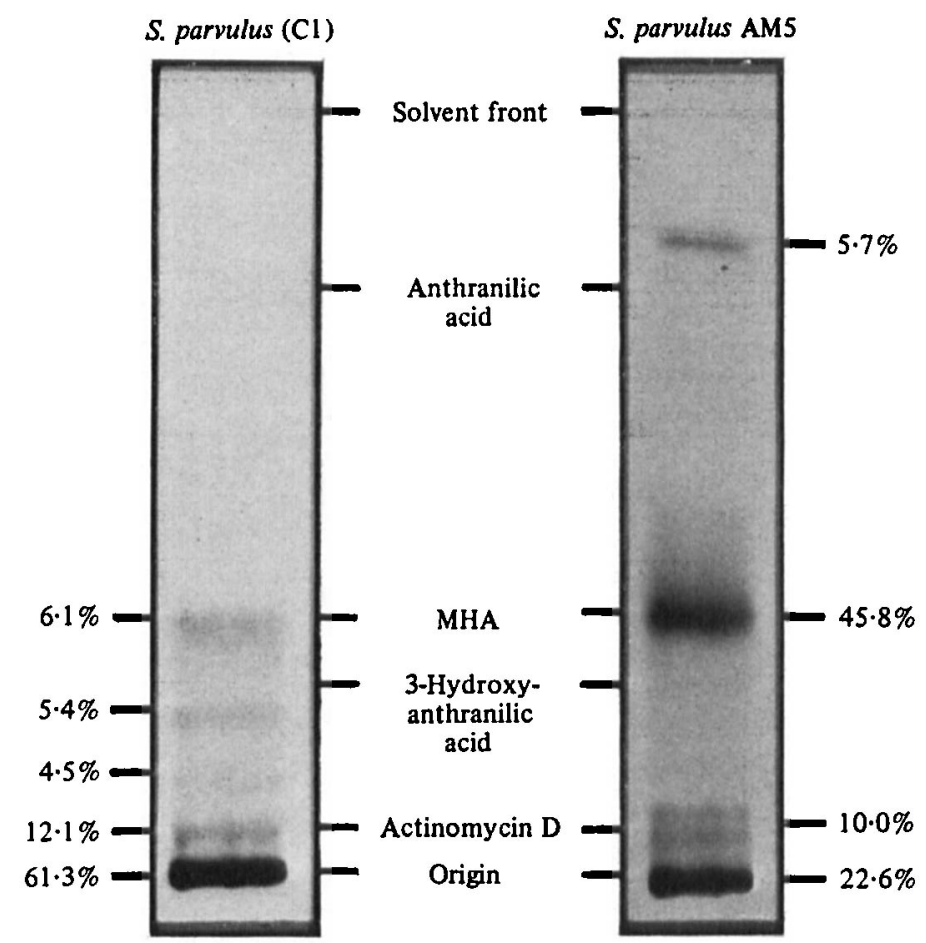

Fig. 4. Autoradiogram of a t.l.c. plate (solvent 1) of peak eluate fractions from Dowex-1 chloride chromatography (see Fig. 3). After autoradiography, the relative amount of each component was determined by scanning with an Ortec densitometer (model no. 4310) equipped with integrator.

properties to the actinocin prepared with the enzyme and authentic MHA (Katz \& Weissbach, 1962). The major compound synthesized was actinocin (t.l.c. solvent $2, R_{F}=0 \cdot 15$ ); however, two additional radioactive substances with higher $R_{F}$ values $(0.79,0.93)$ were also produced. The radioactive MHA completely disappeared after the 20 min incubation, with most of the ${ }^{14} \mathrm{C}$ appearing in actinocin. By contrast, there was no conversion of the ${ }^{14} \mathrm{C}$-labelled metabolite or unlabelled MHA to actinocin when a boiled enzyme preparation was used.

When the ${ }^{14} \mathrm{C}$-labelled compound was incubated with a washed mycelial suspension of S. parvulus (C1) under suitable conditions (Golub et al., 1969), we observed that the purified $\left[{ }^{14} \mathrm{C}\right] \mathrm{MHA}$ was utilized for actinomycin D synthesis by $S$. parvulus. No $\left[{ }^{14} \mathrm{C}\right] \mathrm{MHA}$ accumulated intracellularly, suggesting that the metabolite was rapidly utilized for actinomycin synthesis upon entry into the cell, or that its conversion to the chromophore of the actinomycin molecule occurs on or in the plasma membrane.

\section{Utilization of variously ${ }^{14} \mathrm{C}$-labelled tryptophans as precursor of $M H A$}

Incorporation of ${ }^{14} \mathrm{C}$ from tryptophan into ethyl acetate-extractable metabolites (actinomycin D or MHA) was investigated further using tryptophan labelled with ${ }^{14} \mathrm{C}$ in various ways (side chain, uniformly, or benzene ring). Analysis by t.l.c. revealed that labelled actinomycin was synthesized by the parent (C) and the mutant (AM5) only from benzene ring- and uniformly-labelled tryptophan, and not from side chain-labelled tryptophan. With the first two precursors, synthesis of labelled MHA by the AM5 mutant was also clearly evident, whereas no MHA was detected when the side chain-labelled amino acid was provided. These results suggest that only the benzenoid moiety of tryptophan is used for MHA biosynthesis. 


\section{MHA synthesis by protoplasts derived from $S$. parvulus AM5}

Previous investigations (Keller \& Kleinkauf, 1977; Hitchcock \& Katz, 1978) have shown that there are a number of distinguishing physiological and biochemical differences (e.g. osmotic stability, sensitivity to actinomycin D, influence of amino acid analogues, transport of solutes, rates of biosynthesis) between intact mycelium and protoplasts obtained from $S$. parvulus and $S$. antibioticus cultures. We therefore examined protoplast preparations from the parent and AM5 mutant with respect to MHA formation, using [benzene ring- $\left.\mathrm{U}-{ }^{14} \mathrm{C}\right]$ tryptophan and $\mathrm{L}-\left[\right.$ methyl $\left.-{ }^{14} \mathrm{C}\right]$ methionine. As noted with intact mycelium, appreciable MHA synthesis during short-term incubations (60 to $120 \mathrm{~min}$ ) took place only with the protoplasts prepared from the AM5 strain.

\section{DISCUSSION}

Previous reports demonstrating the accumulation of MHA and its role as a precursor of actinomycin were based on isotope dilution experiments (Weissbach et al., 1965a,b), conditions where actinomycin synthesis was restricted (e.g. D-valine inhibition) (Beaven et al., 1967), or during protoplast formation (Keller \& Kleinkauf, 1977). The present investigation provides genetic evidence for the synthesis of MHA in vivo by Act ${ }^{-}$and Act* mutants since the metabolite is not normally detectable with the wild-type strains. Several observations lead us to conclude that the tryptophan metabolite produced by the AM5 mutant is MHA and that it is an intermediate in actinomycin D biosynthesis. (i) The blue fluorescent compound elaborated by the AM5 strain possesses the same chromatographic properties (paper chromatography and t.l.c.) as authentic MHA. (ii) The labelled metabolite formed during incubation with $\left[\right.$ methyl $\left.-{ }^{14} \mathrm{C}\right]$ methionine and benzene ring- or uniformly-labelled tryptophan also exhibited similar chromatographic mobilities. In addition, when purified by silicic acid and Dowex-1 chloride column chromatography, the major peak of radioactivity eluted with carrier MHA. (iii) When the radioactive metabolite was incubated with phenoxazinone synthase, the enzymic product of the reaction had similar chemical, spectral and chromatographic properties to the actinocin prepared chemically or enzymically using authentic MHA (Katz \& Weissbach, 1962; Salzman et al., 1969). (iv) The ${ }^{14} \mathrm{C}$-labelled compound was utilized readily by a washed mycelial preparation of $S$. parvulus (C1) for actinomycin D synthesis. (v) Utilization of tryptophan by the AM5 mutant appears to be rather specific in nature; thus, uniformly- and benzene ring- but not side chain-labelled tryptophan were employed both for MHA and actinomycin D synthesis, indicating that only the benzenoid moiety of tryptophan is used for their respective synthesis.

The nature of the biochemical lesion resulting in MHA accumulation by the Act* (e.g. AM5) or Act $^{-}$strains examined in the present investigation is not yet known.

The mechanism of biosynthesis of several peptide antibiotics is known to be nonribosomal (Katz \& Demain, 1977) and the mechanism of actinomycin biosynthesis is probably similar. Indeed, studies with inhibitors in vivo have shown that the mechanisms of protein and actinomycin synthesis do differ (Katz \& Weissbach, 1963). We therefore propose the following tentative scheme (Fig. 5) for the biosynthesis of an actinomycin molecule and the accumulation of MHA by the Act ${ }^{-}$or Act* mutants. Actinomycin synthesis begins as a consequence of a number of enzymic reactions that provide both the precursor amino acids and MHA (which is derived from L-tryptophan and L-methionine). Following activation, MHA and the relevant amino acids are covalently bound to a multienzyme complex. Formation of the antibiotic peptide is then thought to be initiated by transfer of covalently bound MHA to a covalently bound molecule of threonine to form covalently linked MHA-threonine. Subsequent peptidation reactions would ultimately yield a covalently linked MHA-pentapeptide. Lactone-ring formation may then provide 


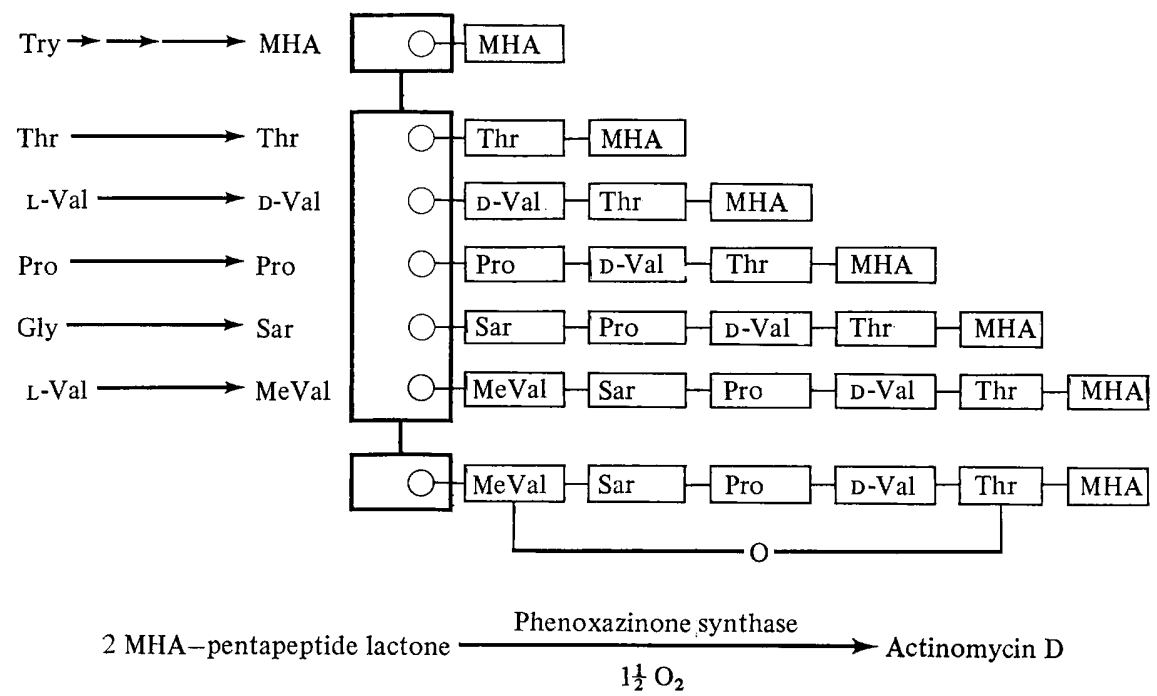

Fig. 5. A possible scheme for the mechanism of biosynthesis of actinomycin $D$ on a protein template.

a mechanism for release of the MHA-pentapeptide from the enzyme complex. The terminal reaction in the synthesis of actinomycin $D$ would involve the oxidative condensation of two molecules of MHA-pentapeptide lactone, catalysed by the enzyme phenoxazinone synthase (Katz \& Weissbach, 1962, 1967; Salzman et al., 1969).

Accumulation of free MHA during actinomycin synthesis might occur as a result of a mutation in a structural gene for an enzyme of the protein template. For example, alteration of the primary structure of the enzyme that catalyses the activation and/or binding of MHA to the multi-enzyme complex might lead to a reduced affinity of the enzyme for its substrate, and/or a reduction in the rate at which MHA can be utilized for actinomycin synthesis. Accumulation of the metabolite might also ensue as a consequence of an enzyme defect that limits the availability of one or more amino acid precursors or their utilization (e.g. activation, modification etc.) by the multi-enzyme template, thereby reducing the flow of MHA into actinomycin D. Alternatively, accumulation of MHA could take place as a consequence of a defect in the regulatory mechanism(s) determining synthesis of the enzymes needed for actinomycin formation. Previous studies have shown that syntheses of actinomycin and several enzymes (tryptophan oxygenase, kynurenine formamidase, hydroxykynureninase, phenoxazinone synthase) in the pathway of actinocin biosynthesis are subject to catabolite repression by glucose and glycerol (Gallo \& Katz, 1972; Troost et al., 1978). These results imply that compounds other than the specific substrates in the pathway (e.g. MHA, amino acids) control the biosynthesis of actinomycin. Thus, it is proposed that a mutation in a specific regulatory component might lead to a reduction in synthesis of the actinomycin multi-enzyme complex without a concomitant reduction in the MHA-synthesizing system. As a consequence, there would be available a larger MHA pool than could be effectively used for actinomycin biosynthesis by the organism.

The role of tryptophan in the biosynthesis of the actinomycin chromophore has been extensively investigated with S. antibioticus (Katz \& Weissbach, 1967) and S. parvulus (Hitchcock \& Katz, 1978). Moreover, Lingens \& Vollprecht (1964) have shown that $S$. antibioticus can convert ${ }^{14} \mathrm{C}$-labelled tryptophan to ${ }^{14} \mathrm{C}$-labelled nicotinic acid. Therefore, a common metabolic pathway from tryptophan appears to supply the relevant precursors needed for biosynthesis of NAD, an end-product of primary metabolism, and of the phenoxazinone moiety of actinomycin, a secondary metabolite (Troost et al., 1978). 
Experiments to elucidate the relationship of the pathway from tryptophan to NAD and the actinomycin chromophore are presently under way.

This investigation was funded through a Public Health Service Research Grant (CA06926) to Edward Katz and a training grant from the National Institute of Allergy and Infectious Diseases (AI-298). We wish to thank Dr Michael Hitchcock for his advice and suggestions with regard to the preparation of protoplasts.

\section{REFERENCES}

Achenbach, H. \& Worth, J. (1977). Michigazon, ein neues Phenoxazon aus Streptomyces michiganensis-Konstitutionsermittlung und Synthese. Chemische Berichte 110, 12-22.

Ahmad, F. \& Moat, A. G. (1966). Nicotinic acid biosynthesis in prototrophs and tryptophan auxotrophs of Saccharomyces cerevisiae. Journal of Biological Chemistry 241, 775-779.

Beadle, G. W., Mitchell, H. K. \& Nyc, J. F. (1947). Kynurenine as an intermediate in the formation of nicotinic acid from tryptophan by Neurospora. Proceedings of the National Academy of Sciences of the United States of America 33, 155-158.

Beaven, V., Barchas, J., Katz, E. \& Weissbach, H. (1967). Studies on the inhibition of actinomycin biosynthesis by D-valine. Journal of Biological Chemistry 242, 657-660.

BraY, G. A. (1960). A simple efficient liquid scintillator for counting aqueous solutions in a liquid scintillation counter. Analytical Biochemistry 1, 279-285.

ButenANDT, A. (1957). Uber Ommochrome, eine Klasse naturlicher Phenoxazon Farbstoff. Angewandte Chemie 69, 16-23.

Butenandt, A. \& Beckman, R. (1955). Uber Ommochrome VI. Mitteilung. Zur Genese von Rhodommatin und Ommatin C. Zeitschrift für physiologische Chemie 301, 115-117.

ButenandT, A. \& Neubert, G. (1955). Uber Ommochrome V. Mitteilung. Xanthommatin, ein Augenfarbstoff der Schmeissfliege Calliophora erythrocephala. Zeitschrift für physiologische Chemie 301, 109-114.

Butenandt, A., Weidel, W. \& Becker, E. (1940). Kynurenin, als Augenpigment Bildung auslosendes Agens bei Insekten. Naturwissenschaften 28, 6364.

Butenandt, A., Weidel, W. \& Schlossberger, H. (1949). 3-Oxykynurenine als $\mathrm{Cn}^{+}$-Genabhangiges Glied in intermediaren Tryptophan-Stoffwechsel. Zeitschrift für Naturforschung 4b, 242-244.

Chaykin, S. (1967). Nicotinamide coenzymes. Annual Review of Biochemistry 36, 149-170.

Delić, V., Hopwood, D. A. \& Friend, E. J. (1970). Mutagenesis by $N$-methyl- $N^{\prime}$-nitro- $N$-nitrosoguanidine(NTG) in Streptomyces coelicolor. Mutation Research 9, 167-182.

Gallo, M. \& KaTz, E. (1972). Regulation of secondary metabolite biosynthesis: catabolite repression of phenoxazinone synthase and actinomycin formation by glucose. Journal of Bacteriology 109, 659-667.
Gerber, N. (1973). Phenoxazinones. In Handbook of Microbiology, vol. III, Microbial Products, p. 333. Edited by A. Laskin \& H. Lechevalier. Cleveland, Ohio: CRC Press.

Golub, E. E., Ward, M. A. \& Nishimura, J. S. (1969). Biosynthesis of the actinomycin chromophore: incorporation of 3-hydroxy-4-methylanthranilic acid into actinomycins by Streptomyces antibioticus. Journal of Bacteriology 100, 977984.

Grove, D. C. \& Randall, W. H. (1955). Assay Methods of Antibiotics, Antibiotics Monograph No. 2, p. 35. New York: Medical Encyclopedia.

Hiтchock, M. J. M. \& Katz, E. (1978). Actinomycin biosynthesis by protoplasts derived from Streptomyces parvulus. Antimicrobial Agents and Chemotherapy 13, 104-114.

Hook, D. J. \& VINING, L. C. (1973). Biosynthetic precursors of etamycin, a peptidolactone antibiotic from Streptomyces griseoviridus. Canadian Journal of Biochemistry 51, 1630-1637.

IChiKaWa, T., Date, M., Ishikura, T. \& OzaKI, A. (1971). Improvement of Kasugamycin-producing strain by the agar piece method and the prototrophic method. Folia microbiologica 16, 218 224.

Katz, E. \& Demain, A. (1977). The peptide antibiotics of Bacillus: chemistry, biogenesis and possible functions. Bacteriological Reviews 41, 449-474.

KatZ, E. \& Weissbach, H. (1962). Biosynthesis of the actinomycin chromophore: enzymatic conversion of 4-methyl-3-hydroxyanthranilic acid to actinocin. Journal of Biological Chemistry 237, 882-886.

KATZ, E. \& WeISSBACH, H. (1963). Incorporation of $\mathrm{C}^{14}$-labeled amino acids into actinomycin and protein by Streptomyces antibioticus. Journal of Biological Chemistry 238, 666-675.

KatZ, E. \& Weissbach, H. (1967). Studies on the cell-free synthesis of actinomycins. Developments in Industrial Microbiology 8, 67-87.

Keller, U. \& Kleinkauf, H. (1977). Studies of the biosynthesis of actinomycin in protoplasts from Streptomyces antibioticus. Archives of Biochemistry and Biophysics 184, 111-124.

Kelner, A. (1948). Mutation in Streptomyces flaveolus induced by X-rays and ultraviolet light. Journal of Bacteriology 56, 457-465.

Kramer, J., Carter, G. G., Arret, B. Wilner, J., Wright, W. W. \& Kirschbaum, A. (1968). Antibiotic Residues in Milk, Dairy Products and Animal Tissue: Methods, Reports and Protocols, 
Part I. Washington: National Center for Antibiotic and Insulin Analysis, U.S. Department of H.E.W.

Krebs, K. G., Heusser, D. \& Wimmer, H. (1969). Spray Reagents. In Thin-Layer Chromatography, pp. 854-909. Edited by E. Stahl. New York: Springer-Verlag.

Lingens, F. \& Vollprecht, P. (1964). Zur Biosynthesedie Nicotinsaure in Streptomyceten, Algen, Phycomyceten und Hefe. Zeitschrift für physiologische Chemie 339, 64-75.

Lingens, F., Vollprecht, P. \& Gildemeister, V. (1966). Zur Biosynthese der Nicotinsaure in Xanthomonas- und Pseudomonas-Arten, Mycobacterium phlei und Rotalgen. Biochemische Zeitschrift 344, 462-477.

LINZEN, B. (1974). The tryptophan-ommochrome pathway in insects. Advances in Insect Physiology 10, 117-246.

MeIenhofer, J. \& Atherton, E. (1973). Structureactivity relationships in the actinomycins. $A d$ vances in Applied Microbiology 16, 203-300.

Parada, J. L. (1975). Selective filtration in the isolation of independent clones of Streptomyces. Applied Microbiology 29, 13-16.

Salzman, L. H., Weissbach, H. \& Katz, E. (1969). Enzymatic synthesis of actinocinylpeptides. Archives of Biochemistry and Biophysics 130, 536-546.

TAtum, E. L. (1939). Development of eye colors in Drosophila. Bacterial synthesis of $\mathrm{V}^{+}$hormone. Proceedings of the National Academy of Sciences of the United States of America 25, 486-490.
TAtum, E. L. \& HaAgen-Smit, A. J. (1941). Identification of Drosophila $\mathrm{V}^{+}$hormone of bacterial origin. Journal of Biological Chemistry 140, 575580.

TownSEND, M. E., Wright, H. M. \& Hopwood, D. A. (1971). Efficient mutagenesis by near ultraviolet light in the presence of 8-methoxypsoralen in Streptomyces. Journal of Applied Bacteriology 34, 799-801.

Troost, T., Brown, D., Hitchcock, M. \& Katz, E. (1978). The role of primary metabolism in the biosynthesis of a secondary metabolite. Bacteriological Proceedings, 185.

Weissbach, H., Redfield, B., Beaven, V. \& Katz, E. (1965a). 4-Methyl-3-hydroxyanthranilic acid, an intermediate in actinomycin biosynthesis. Biochemical and Biophysical Research Communications 19, 524-530.

Weissbach, H., Redfield, B. G., Beaven, V. \& KATZ, E. $(1965 b)$. Actinomycin synthesis in washed cells of Streptomyces antibioticus. Journal of Biological Chemistry 240, 4377-4381.

Williams, W. K. \& Katz, E. (1977). Development of a chemically defined medium for the synthesis of actinomycin D by Streptomyces parvulus. Antimicrobial Agents and Chemotherapy 11, 281-290.

Wilson, R. G. \& Henderson, L. M. (1963). Tryptophan-niacin relationship in Xanthomonas pruni. Journal of Bacteriology 85, 221-229. 